\title{
Aspects of the Influence of Light on the Adsorption and Electrooxidation of Allyl Alcohol on Pt/Pt Electrodes in Perchloric Acid Solutions
}

\author{
Claudia Smaniotto Barin, and Reinaldo Simões Gonçalves* \\ Universidade Federal de Santa Maria, C.P. 5061, 97105-900 Santa Maria -RS - Brazil
}

Received: April 3, 1998

\begin{abstract}
Neste trabalho são apresentados alguns aspectos da eletrooxidação de espécies adsorvidas, formadas durante a adsorção do álcool alílico sobre o eletrodo de platina platinizada, em $\mathrm{HClO}_{4} 1,0$ M. A quantidade máxima de intermediários adsorvidos formados, ocorreu quando o potencial de adsorção foi fixado em, $\mathrm{E}_{\mathrm{ads}}=0,00 \mathrm{~V}$ (ECS). Estudos cronoamperométricos realizados neste potencial, confirmam que a corrente associada ao processo de adsorção do hidrogênio, diminui na presença do composto orgânico. O álcool alílico desloca o hidrogênio adsorvido sobre os sítios ativos. A incidência de luz policromática sobre o eletrodo aumenta o efeito inibidor, quando se compara o mesmo ensaio no escuro. A eletrooxidação das espécies formadas envolve um processo monoeletrônico de transferência de carga. A corrente anódica ligada a este processo, foi maior no meio iluminado do que no escuro. Esta diferença foi atribuída à um efeito fotoindutor: ou sobre o processo de adsorção do álcool alílico sobre $\mathrm{Pt} / \mathrm{Pt}$; ou sobre a eletrooxidação das espécies adsorvidas. A eletrooxidação destas espécies adsorvidas demanda uma energia de ativação aparente de 33,3 $\mathrm{kJ} / \mathrm{mol}$ no escuro e, $24,9 \mathrm{~kJ} / \mathrm{mol}$ no ambiente iluminado.
\end{abstract}

The electrooxidation of the adsorbed species produced by allyl alcohol adsorption on platinized platinum electrode has been studied in $1.0 \mathrm{M} \mathrm{HClO}_{4}$ medium. The maximum amount of adsorbed intermediates formed during allyl alcohol adsorption on the electrode surface, was observed at the adsorption potential, $\mathrm{E}_{\mathrm{ads}}=0.00 \mathrm{~V}$ (SCE). Chronoamperometric studies at this potential confirm that the current associated with the hydrogen adsorption process decreases in the presence of the organic compound. Allyl alcohol displaces adsorbed hydrogen at the active sites. The incidence of polychromatic light on the electrode improves this effect as shown by comparison with the same experiments in the darkness. However, the electrooxidation of the adsorbed species comprise a monoelectronic charge transfer step. The anodic current associated with this process was higher under illumination than in the dark. This difference was attributed to a light-induced effect: either on the adsorption process of allyl alcohol on $\mathrm{Pt} / \mathrm{Pt}$, or on the electrooxidation of the adsorbed species. The electrooxidation of the adsorbed species formed during allyl alcohol adsorption demands apparent activation energies equivalent to 33.3 $\mathrm{kJ} \mathrm{mol}^{-1}$ and $24.9 \mathrm{~kJ} \mathrm{~mol}^{-1}$ in the dark and under illumination, respectively.

Keywords: allyl alcohol, photo-effects, electrooxidation, adsorption, platinum platinized electrode

\section{Introduction}

The kinetics of electrocatalytic reactions at solid electrodes reveal that different parameters govern the oxidation reaction. It has been found that the electrochemical activity on noble electrodes depends on the nature of the organic compound $^{1}$ and electrode potential ${ }^{2}$.

The process of the electrooxidation of a primary alcohol on gold ${ }^{3}$ and on platinum electrodes ${ }^{4}$ in aqueous acid solutions depends on the difference of adsorbability of the organic reagents as well as on the structure of the intermediates produced by chemisorption. The possible structure of adsorbed species depends on the destructive or non-destructive character of the chemisorption. It was observed that the electrooxidation of allyl alcohol adsorbates produces only $\mathrm{CO}_{2}$ and, in this case, the adsorption process of allyl alcohol on platinum electrode has a destructive character ${ }^{4}$. 
The effect of the incidence of the light on the electrooxidation of adsorbed organic compounds in diluted sulfuric acid was published elsewhere 5 . It was observed that the electrooxidation process of the adsorbed species formed during allyl alcohol adsorption was affected by the incidence of polychromatic light on the electrode surface. However, the effect of the light on the adsorption process was not obvious in sulfuric acid solutions.

This paper concerns the study of the adsorption and electrooxidation of allyl alcohol on platinum platinized electrode in diluted perchloric acid. The influence of the incidence of polychromatic light on the catalytic activity of platinum platinized electrode was also studied. Some experiments were made in darkness in order to compare the effect of the light. Data were obtained by cyclic voltammetry and chronoamperometry. Different reaction parameters were studied: a)the allyl alcohol concentration $\left(\mathrm{C}_{\mathrm{AA}}\right)$; b)the illumination conditions; c)the adsorption potential $\left.\left(E_{a d s}\right) ; d\right)$ the adsorption time $\left(t_{a d s}\right)$; e)the potential sweep rate (v) and, f)the temperature of the solution.

\section{Experimental}

\section{Cell and electrodes}

Experiments were carried out in a $250 \mathrm{~mL}$ three electrode electrochemical cell made with a cylindrical transparent glass Duran-50. A platinum counter-electrode and a saturated calomel electrode as reference, were used. The working electrode was a platinum platinized wire. To calculate the current densities, the true surface area of the platinum electrode was evaluated from the hydrogen adsorption-desorption potential region. A voltammogram recorded in the supporting electrolyte alone was used, assuming $210 \mu \mathrm{C} \mathrm{cm}^{-2}$ for an adsorbed monolayer. All experiments were made under static conditions. The working electrode was activated in the supporting electrolyte through a triangular potential scan between the onset hydrogen and oxygen evolution, until a reproducible voltammogram was attained. Before each voltammogram a potential programm in this potential range was applied on the working electrode in order to clean the electrode surface. Adsorption potentials and adsorption times were experimentally determined.

\section{Apparatus}

The electronic set-up consisted of a PAR 173 potentiostat, a PAR 175 universal programmer and a PAR RE0089 x-y recorder. The light source was a slide projector with a $150 \mathrm{~W}$ lamp. It was kept fixed and glass lenses were used in order to collimate the light beam directly on the electrode surface. It was positioned near the glass wall. The temperature was kept constant, to an accuracy of $1 \mathrm{~K}$, by passing water thermostatically controlled through a glass tube inside the cell. Measurements made without a thermal control showed that the temperature of the solution near the electrode surface increases by $0.5^{\circ} \mathrm{C}$ only. This result may mean that the thermal effect of the light dispersion is under control and, it is not important during the experimental time delay.

\section{Electrolyte}

The aqueous supporting electrolyte solutions used in this work were 1.0 M in perchloric acid. They were prepared from ultrapure water obtained with a Millipore Milli Q system and Merck (p.a.) perchloric acid. The allyl alcohol was pure Riedel-de Haën. Prior to the experiments, the supporting electrolyte solution was deoxygenated by bubbling pure $\mathrm{N}_{2}$ through it.

\section{Results and Discussion}

\section{Effect of the light}

The measurements were performed after a preactivation potential program applied to the working electrode before each experiment as described elsewhere ${ }^{2}$. The potentiodynamic $\mathrm{I}(\mathrm{E})$ profiles, at different illumination conditions, are shown in Fig. 1. The $\mathrm{I}(\mathrm{E})$ curves derived from allyl alcohol adsorption exhibit an electrochemically irreversible anodic peak during the positive scan at $\mathrm{v}=0.40$ $\mathrm{V} / \mathrm{s}$. This one is connected to the direct electrooxidation of the adsorbed species formed during allyl alcohol adsorp-

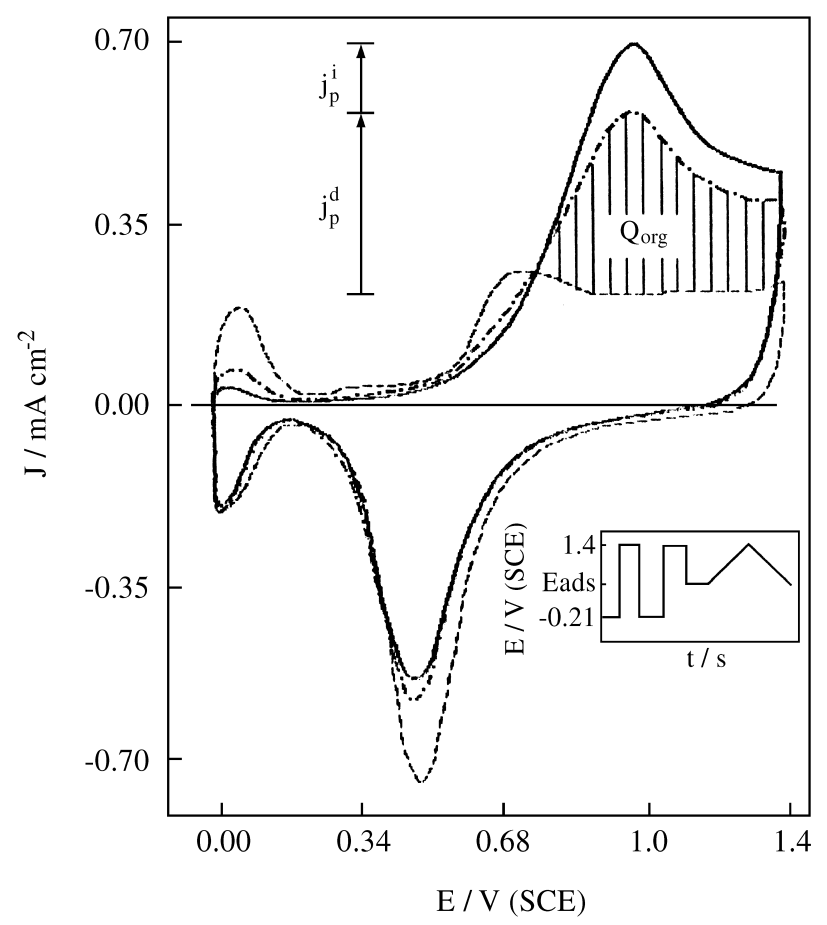

Figure 1. Potentiodynamic I(E) profiles of a platinized platinum electrode in deaerated $1.0 \mathrm{M} \mathrm{HClO}_{4}$, in the absence (----) and presence of allyl alcohol $0.50 \mathrm{mM}$ at $\mathrm{E}_{\mathrm{ads}}=0.0 \mathrm{~V}(\mathrm{SCE}), \mathrm{tads}=180 \mathrm{~s}, \mathrm{v}=0.40 \mathrm{~V} / \mathrm{s}$, in the dark (- - ) and under illumination (-). 
tion on the electrode surface. The current densities linked to this process depend on the illumination conditions. The region labeled, Qorg, between the curves in the presence and in the absence of allyl alcohol, is related to the quantity of electricity connected with the electrooxidation of adsorbed species formed during allyl alcohol adsorption. Qorg, is determined by integration of the surface under the peak. The current density peak concerning to the electrooxidation of the adsorbed species was labeled $\left(\mathrm{j}_{\mathrm{p}} \mathrm{d}\right)$, for the experiments in the dark and $\left(j_{\mathrm{p}} \mathrm{I}\right)$, for the experiments under illumination. Both data, $\mathrm{j}_{\mathrm{p}}$, and $\mathrm{Q}_{\mathrm{org}}$, were greater when the system was under illumination than in the dark. This difference may be associated with the amount of adsorbed species formed on the electrode surface that increases when the system is under illumination. Spectroscopic studies concerning the adsorption of ethanol on polycrystalline platinum electrode show that adsorbed carbon monoxide, and other $\mathrm{C}, \mathrm{O}, \mathrm{H}$ containing species are formed at the $\mathrm{Pt}$ surface $^{6}$. It should be pointed out that the incidence of polychromatic light on the electrode surface may increase the amount of these species formed in this process.

It was suggested in the literature that the mechanism of the electrooxidation of the adsorbed species formed during ethanol adsorption on platinum electrodes involves a process that depends on the quantity of $\mathrm{HO}_{\text {ads }}$ formed during water adsorption ${ }^{7}$ such as:

$$
\mathrm{CO}_{\mathrm{ads}}+\mathrm{HO}_{\mathrm{ads}} \longrightarrow \mathrm{OCO}+\mathrm{H}^{+}+\mathrm{e}^{-}
$$

In this connection it should be appropriate to presume that both processes related with allyl alcohol adsorption and water adsorption are being affected by the incidence of polychromatic light on the electrode surface. This could explain the effect of the incidence of polychromatic light on the current densities observed during the electrooxidation of the adsorbed organic species.

In the potential region where the hydrogen adsorptiondesorption occurs, another interesting point can also be seen from the current densities associated with the electrooxidation of adsorbed hydrogen. They decrease in the presence of allyl alcohol in solution. This observation suggests that the adsorbed hydrogen is being displaced. However, this effect was noticeable when the electrode was under illumination. The incidence of polychromatic light on the electrode surface may improve the adsorption process of allyl alcohol on the electrode surface. Some experimental measurements in $1.0 \mathrm{~N} \mathrm{H}_{2} \mathrm{SO}_{4}$ did not show this influence $^{5}$. This can conceivably be attributed to the fact that $\mathrm{HSO}_{4}$ - ions adsorbed on $\mathrm{Pt}^{8}$ seem to exert long-range effects through the formation of hydrogen bonds with water ${ }^{9}$. It would perhaps be reasonable to suggest that the incidence of polychromatic light on the electrode surface may induce new adsorption products regarding to the adsorbed species formed in perchloric acid solutions.

\section{Effect of the adsorption potential}

The dependence of I(E) curves on the adsorption potential, $E_{a d s}$, is shown in Fig. 2. The voltammograms were taken at different adsorption potentials in the absence and in the presence of $5.0 \mathrm{mM}$ of allyl alcohol. The adsorption time for this allyl alcohol concentration was $30 \mathrm{~s}$ in order to prevent some problems involving coverage of the electrode. The current densities associated with the electrooxidation of the adsorbed species increase when the electrode potential is polarized at a more positive value. This obviously suggests that the coverage of the electrode surface by adsorbed species formed during allyl alcohol adsorption grows when the electrode was polarized more anodically.

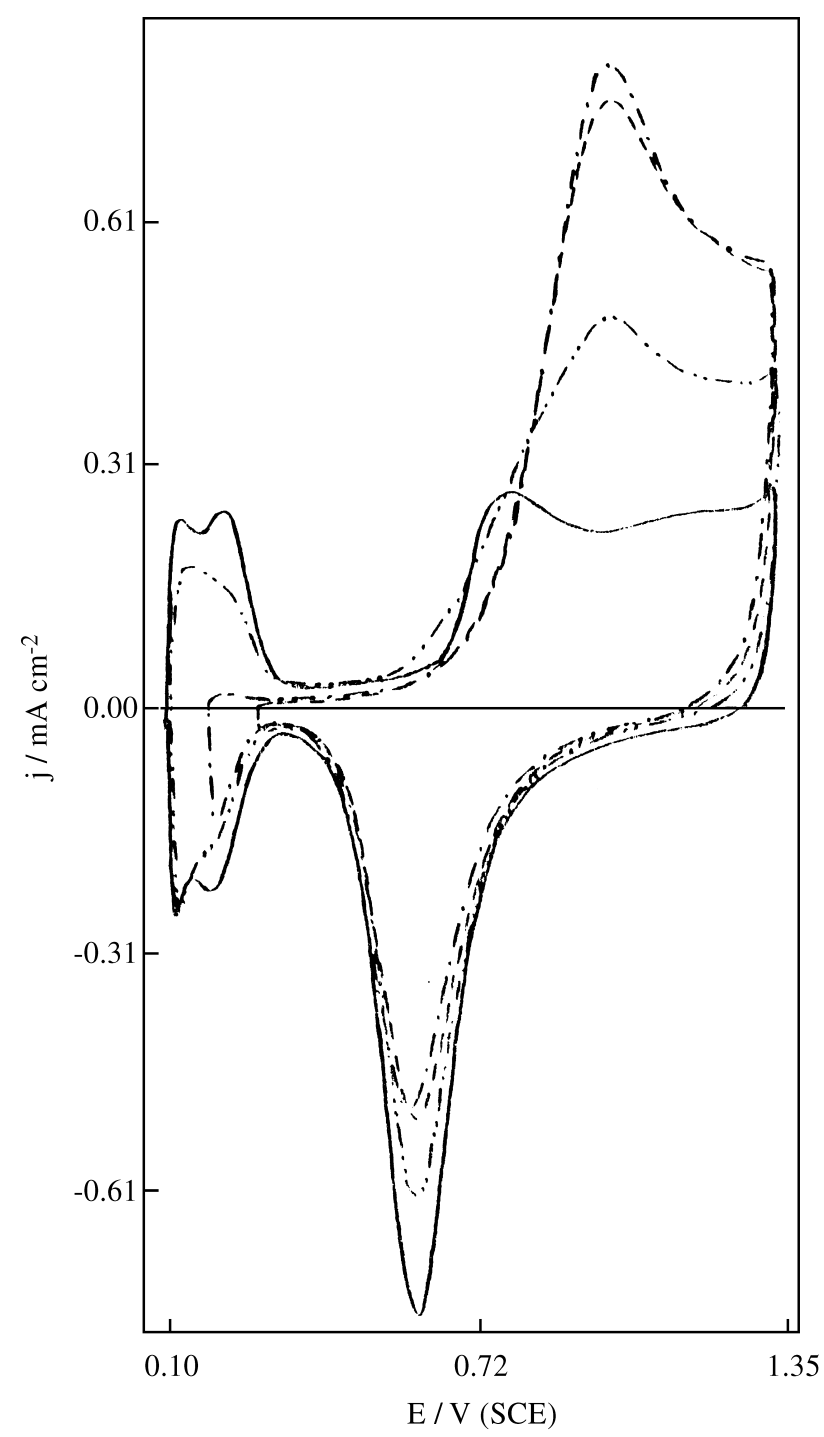

Figure 2. Potentiodynamic I(E) profiles of a platinized platinum electrode in deaerated 1.0 $\mathrm{M} \mathrm{HClO}_{4}$ in absence (-) and in the presence of allyl alcohol 5.0 mM, at different adsorption potentials: Eads $=-0.10 \mathrm{~V}(--)$; $\mathrm{E}_{\mathrm{ads}}=-0.05 \mathrm{~V}(---) ; \mathrm{E}_{\mathrm{ads}}=0.00 \mathrm{~V}(--)$, under illumination, $\mathrm{v}=0.40 \mathrm{~V} / \mathrm{s}$, $25^{\circ} \mathrm{C}$ and, tads $=30 \mathrm{~s}$. 
The electroreduction of platinum oxide was observed during the cathodic potential sweep. The current densities related with this process, decrease in the presence of the organic compound and, depend also on the adsorption potential.

The potential range at which $Q_{\text {org }}$ was maximum varied between $-0.05 \mathrm{~V}$ (SCE) and $+0.05 \mathrm{~V}$ (SCE) as is shown in Fig. 3. The incidence of polychromatic light on the electrode surface, increases $Q_{\text {org values. The highest }} \mathrm{Q}_{\text {org value }}$ was observed at $0.0 \mathrm{~V}$ (SCE). The same behavior was observed by plotting the current density values, $\left(\mathrm{j}_{\mathrm{p}}\right)$, vs. adsorption potential as is shown in Fig. 4. For a $1.0 \mathrm{M}$ $\mathrm{HClO}_{4}$ solution the adsorption potential $\left(\mathrm{E}_{\mathrm{ads}}\right)$, of allyl alcohol on Pt/Pt electrodes was fixed at $0.0 \mathrm{~V}$ (SCE). The dependence of the interaction between the organic compound and the electrode surface with the adsorption potential was discussed elsewhere ${ }^{2}$.

The adsorption process of organic substances at electrodes depends on a great number of parameters ${ }^{10}$. However, the effect of the incidence of light on the electrode surface during adsorption and electrooxidation of the adsorbed species was not found in the literature. This phenomena may be due to:

a) a photo-activation of the adsorption process of allyl alcohol on the electrode surface or,

b) a photo-activation of the electrooxidation of the adsorbed species formed during allyl alcohol adsorption.

\section{Effect of the adsorption time}

The interaction between allyl alcohol and the electrode surface has been investigated as a function of adsorption time. Figure 5 shows the voltammograms in the absence

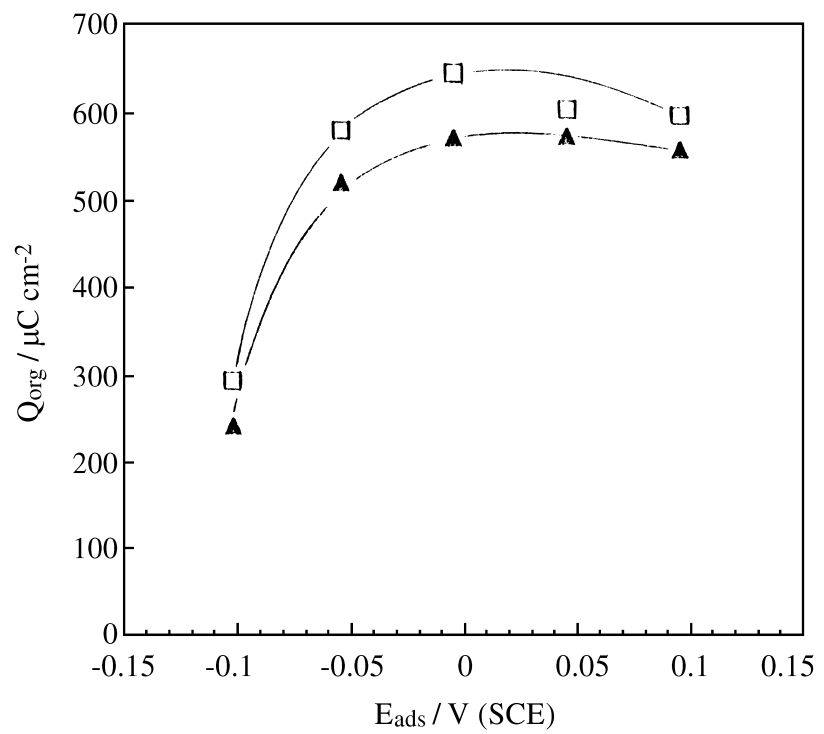

Figure 3. Effect of the adsorption potential, $E_{a d s}$, on the quantity of electricity, Qorg, necessary to oxidize the adsorbed species formed during allyl alcohol adsorption $5.0 \mathrm{mM}$, in deaerated $1.0 \mathrm{M} \mathrm{HClO}_{4}$, in the dark $(\mathbf{\Delta})$ and under illumination $(\square)$. and presence of allyl alcohol at different adsorption times: $\mathrm{t}_{\mathrm{ads}}=30 \mathrm{~s}$ and $\mathrm{t}_{\mathrm{ads}}=180 \mathrm{~s}$. The measurements were conducted by keeping the electrode potential at $\mathrm{E}_{\mathrm{ads}}=0.0 \mathrm{~V}$

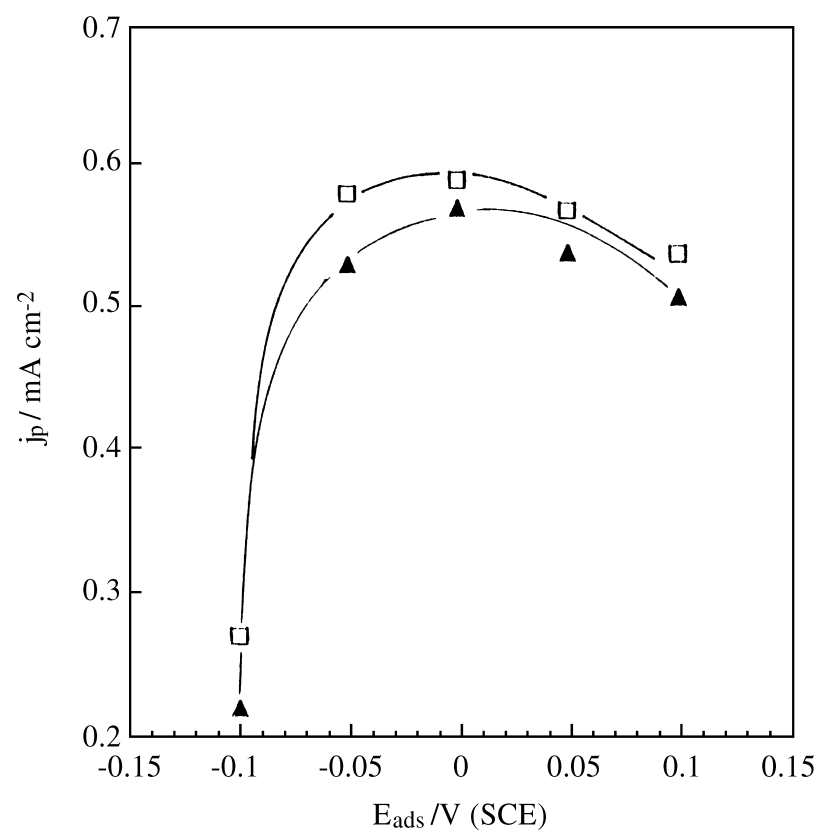

Figure 4. Effect of the adsorption potential Eads on the current densities $\mathrm{j}_{\mathrm{p}}$ related with the peak of the electrooxidation of the adsorbed species formed during allyl alcohol adsorption $5.0 \mathrm{mM}$, in the dark $(\boldsymbol{\Delta})$ and, under illumination $(\square$.

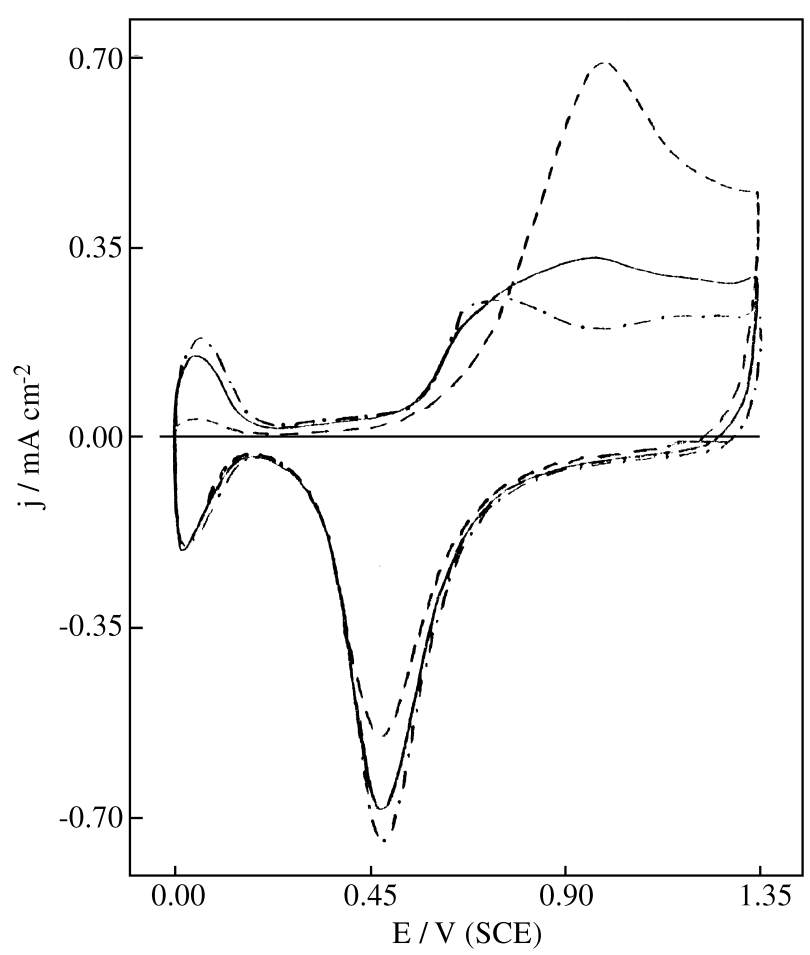

Figure 5. Effect of the adsorption times $t_{a d s}$ on the $\mathrm{I}(\mathrm{E})$ curves, in deaerated $1.0 \mathrm{M} \mathrm{HClO}_{4}$, under illumination, at $\mathrm{v}=0.40 \mathrm{~V} / \mathrm{s}, 25{ }^{\circ} \mathrm{C}$, $\mathrm{E}_{\text {ads }}=0.0 \mathrm{~V}$ (SCE), in the absence (- - ) and presence of $0.50 \mathrm{mM}$ of allyl alcohol during tads $=30 \mathrm{~s}(-)$ and, tads $=180 \mathrm{~s}(---)$. 
(SCE) during these times. The potential sweep rate was $\mathrm{v}=0.40 \mathrm{~V} / \mathrm{s}$. As the adsorption time increases, a strong effect appears on both sides of the voltammogram. The changes in the hydrogen adsorption/desorption potential range show that the presence of allyl alcohol decreases the current densities associated with the electrooxidation of adsorbed hydrogen. This means that the active sites on the electrode surface were blocked by the species formed during allyl alcohol adsorption. This inhibition was noticeable at long adsorption times.

The changes in the platinum oxidation/reduction potential range display that the process depends also on the adsorption times. The current densities related with the electrooxidation of the adsorbed species formed on the electrode surface depend on the polarization time at that adsorption potential.

\section{Effect of the voltage sweep rate variation}

The potentiodynamic I(E) profiles at different potential sweep rates, recorded after adsorption of allyl alcohol, according to the conditions determined before, are shown in Fig. 6. The current densities related with both anodic and cathodic processes increase proportionally by increasing

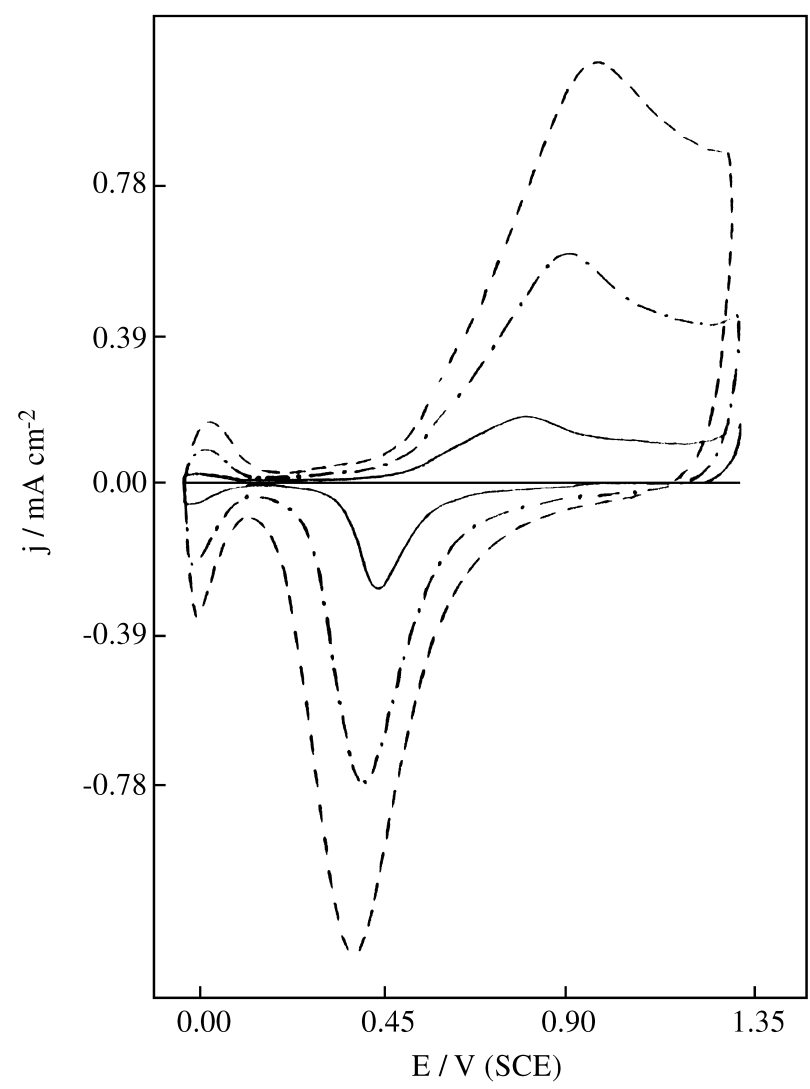

Figure 6. Potentiodynamic I(E) profiles at different voltage sweep rates (v), in the dark, in the presence of allyl alcohol $0.50 \mathrm{mM}, 25{ }^{\circ} \mathrm{C}$, $\mathrm{E}_{\mathrm{ads}}=0.0 \mathrm{~V}(\mathrm{SCE}), \mathrm{t}_{\mathrm{ads}}=180 \mathrm{~s}$, at $\mathrm{v}=0.10 \mathrm{~V} / \mathrm{s}(-), \mathrm{v}=0.40 \mathrm{~V} / \mathrm{s}(--)$ and $\mathrm{v}=0.80 \mathrm{~V} / \mathrm{s}(----)$. the potential sweep rate. The shape of the voltammograms did not change at high sweep rate. However, the potential of the oxidation peak associated with the electrooxidation of the adsorbed species is shifted towards more positive potential values by increasing the sweep rate.

In order to complete the characterization of the effect of the illumination on the electrode surface, Fig. 7 shows the variation of $Q_{\text {org }}$, corresponding to the electrooxidation of the adsorbed species derived from allyl alcohol, at different sweep rates. The amount of charge, $Q_{\text {org }}$, decreases when the sweep rate increases. The re-adsorption process of allyl alcohol on the electrode surface is occurring at low sweep rate. The re-adsorption process of allyl alcohol on the active sites of the electrode surface decreases at high sweep rate. However, the influence of the incidence of polychromatic light was noticeable for all studied sweep rates. The higher $Q_{\text {org values observed when the electrode }}$ surface was irradiated with polychromatic light is in agreement with the results obtained before. The process of the electrooxidation of adsorbed species, formed during allyl alcohol adsorption, was affected by the incidence of the light. It appears that the adsorbed species formed in the dark were not different from that formed under illumination.

The potential of the anodic peak related with the electrooxidation of adsorbed species varies linearly with $\log (\mathrm{v})$, yielding a slope of $183 \mathrm{mV} / \mathrm{dec}$ under illumination and $214 \mathrm{mV} / \mathrm{dec}$ in the dark. These results correspond to $\alpha \mathrm{n} \cong 0.3$, which confirm that a monoelectronic charge transfer step is probably the rate determining step for the oxidation reaction of the same adsorbed species.

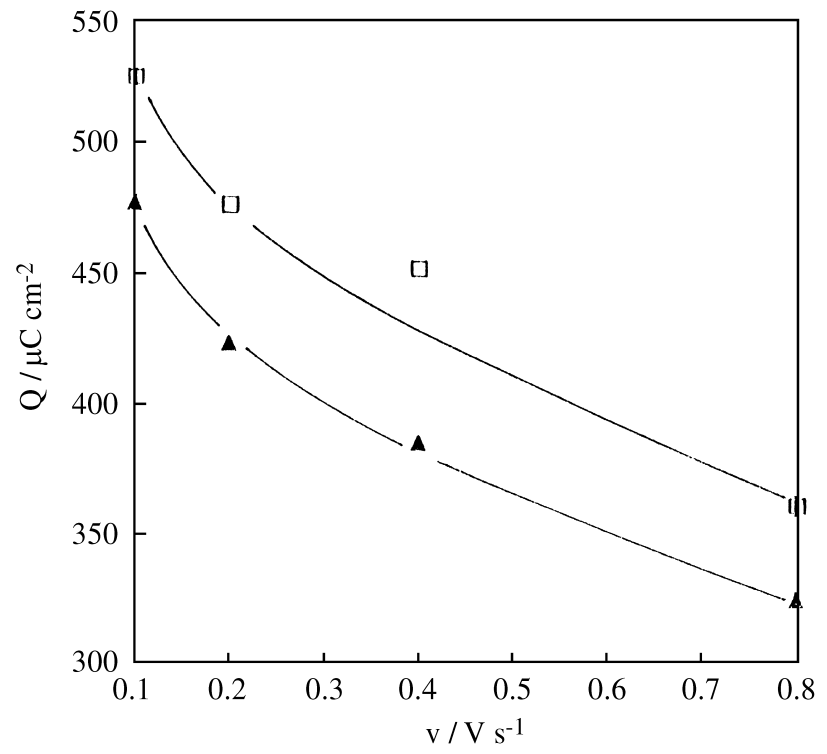

Figure 7. Effect of the potential sweep rate variation on the quantity of electricity $\left(Q_{o r g}\right)$ necessary to oxidize the adsorbed species formed during allyl alcohol adsorption, $\mathrm{C}_{\mathrm{AA}}=0.50 \mathrm{mM}, 25{ }^{\circ} \mathrm{C}, \mathrm{E}_{\mathrm{ads}}=0.0 \mathrm{~V}(\mathrm{SCE})$, $\mathrm{t}_{\mathrm{ads}}=180 \mathrm{~s}$, in the dark $(\mathbf{\Lambda})$ and under illumination $(\square)$. 


\section{Effect of allyl alcohol concentration}

Figure 8 shows the I(E) curves, at two different concentrations of allyl alcohol, recorded after the adsorption of the organic compound on the electrode surface. The voltammogram in the absence of the organic compound is also presented.

The quantity of electricity, associated with the electrooxidation of the adsorbed species increases as the allyl alcohol concentration increases, indicating that the electrode coverage depends on this variable. On the other side, the current densities related with the electrooxidation of adsorbed hydrogen decreases. This is further evidence that the active sites of the electrode surface are being blocked for the hydrogen adsorption. Table 1 completes the characterization concerning the effect of allyl alcohol concentration on $Q_{\text {org. }}$ The influence of the light is also presented. The charge quantities involved in this process suggest that the electrode surface is saturated with the adsorbed species at $\mathrm{C}_{\mathrm{AA}}=1.6 \mathrm{mM}$. The difference, $\Delta \mathrm{Q}_{\text {org }}$, among values under different illumination conditions is larger at low allyl alcohol concentration than in more concentrated solutions. When the electrode is saturated with the adsorbed species this difference decreases. This may suggest that the incidence of the light on the electrode surface is affecting the adsorption process only for low concentrations of the organic compound. The conformation of electrogenerated adsorbed species should be different when the electrode surface is covered partially.

In order to confirm the influence of the light on the adsorption process of allyl alcohol on the electrode surface, some chronoamperometric experiments were made at the adsorption potential, as is shown in Fig. 9. The same potential program was applied on the working electrode as described before. The current densities recorded in the absence and presence of $0.50 \mathrm{mM}$ allyl alcohol were taken at $0.0 \mathrm{~V}$ (SCE). Both species allyl alcohol and hydrogen are competing for the same active sites on the electrode surface at this potential.

The charge related with the hydrogen adsorption decreases in the presence of the organic compound. The species formed during the adsorption process interacts with the active sites of the surface electrode displacing the adsorbed hydrogen. However, this effect was more remarkable when the system was under illumination than in the dark. This may be due to:

a) a photo-activation of the adsorption process of allyl alcohol on the electrode surface;

b) the incidence of light can oscillate the adsorbed species in order to promote a new conformation on the electrode surface;

c) hydrogen desorption process increases when the system is under illumination.

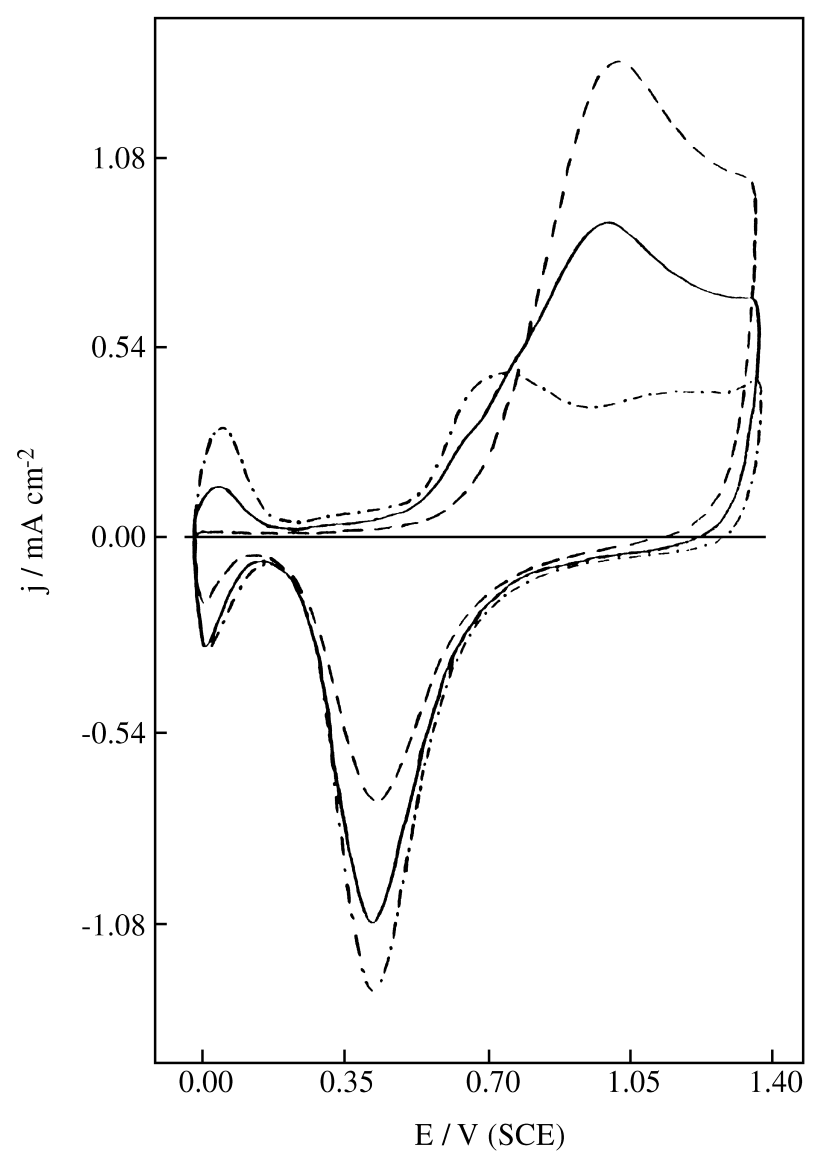

Figure 8. Potentiodynamic $\mathrm{I}(\mathrm{E})$ profiles at different allyl alcohol concentrations, under illumination, $25^{\circ} \mathrm{C}, \mathrm{E}_{\mathrm{ads}}=0.0 \mathrm{~V}(\mathrm{SCE}), \mathrm{t}_{\mathrm{ads}}=180 \mathrm{~s}$, $\mathrm{v}=0.80 \mathrm{~V} / \mathrm{s}$, in the absence (- -) and in the presence of the organic at $\mathrm{C}_{\mathrm{AA}}=0.40 \mathrm{mM}(-)$ and, $\mathrm{C}_{\mathrm{AA}}=10.0 \mathrm{mM}(---)$.

Table 1. Effect of light on the quantity of electricity, Qorg, associated with the electrooxidation of adsorbed species formed during allyl alcohol adsorption at different concentrations, tads $=180 \mathrm{~s}, \mathrm{E}_{\mathrm{ads}}=0.0 \mathrm{~V}$ (SCE), $25^{\circ} \mathrm{C}, \mathrm{v}=0.80 \mathrm{~V} / \mathrm{s}$. The difference, $\Delta \mathrm{Q}_{\text {org }}$, among values is also presented.

\begin{tabular}{lccc}
\hline & \multicolumn{3}{c}{ Qorg $/ \mu \mathrm{C} \mathrm{cm}^{-2}$} \\
\cline { 2 - 4 } $\mathrm{C}_{\mathrm{AA}} / \mathrm{mM}$ & Dark & Illuminated & $\Delta$ Qorg \\
\hline 0.2 & 159.57 & 165.66 & 6.09 \\
0.4 & 243.35 & 279.25 & 35.9 \\
0.8 & 394.94 & 446.80 & 51.9 \\
1.6 & 528.58 & 538.56 & 9.98 \\
2.0 & 530.58 & 540.55 & 9.97 \\
4.0 & 538.56 & 548.53 & 9.97 \\
8.0 & 552.52 & 560.50 & 7.98 \\
10.0 & 556.51 & 572.46 & 16.0 \\
\hline
\end{tabular}

\section{Effect of the temperature}

The potentiodynamic $\mathrm{I}(\mathrm{E})$ profiles for the system at different temperatures, are shown in Fig. 10. The cyclic 


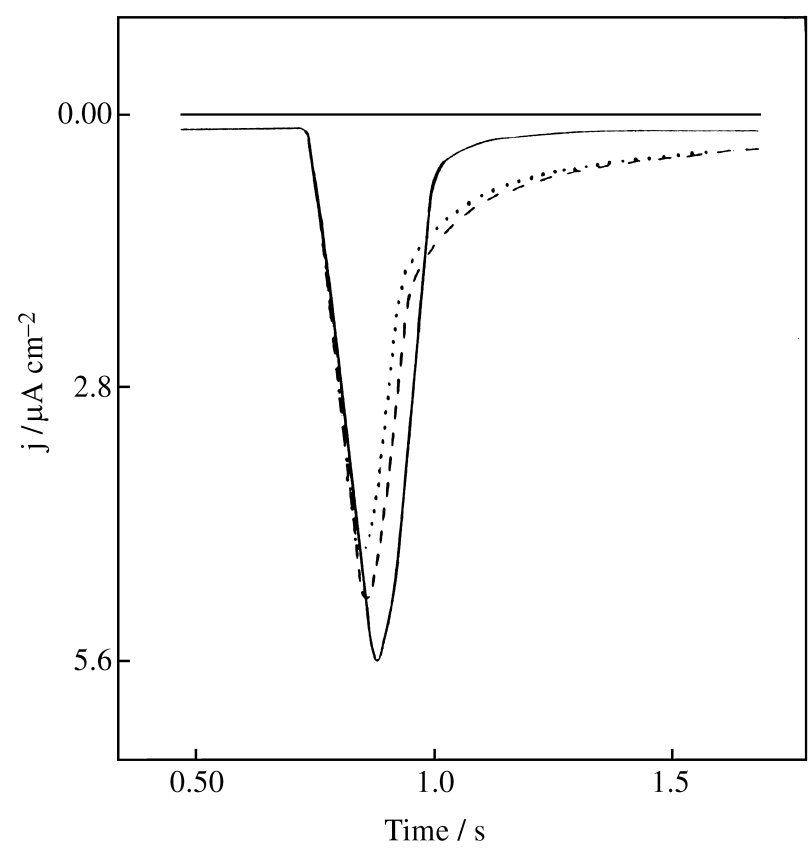

Figure 9. Current $x$ time curves at $E=0.0 \mathrm{~V}$ (SCE) for Pt/Pt electrode in $1.0 \mathrm{M} \mathrm{HClO}_{4}$ in the absence (-) and, presence of $0.5 \mathrm{mM}$ of allyl alcohol in the dark (----) and under illumination (.....).

voltammogram for the base electrolyte without substract is presented at $25^{\circ} \mathrm{C}$.

In the hydrogen adsorption/desorption potential range, the current densities related with the electrooxidation of adsorbed hydrogen decreases in the presence of allyl alcohol when the temperature increases. The interaction between the active sites and the organic compound improves when the temperature increases. The adsorbed hydrogen was more effectively displaced at higher temperature than at lower.

On the other side, the current densities associated with the electrooxidation of adsorbed species formed during allyl alcohol adsorption, increases with temperature. This may indicate that the quantity of adsorbed species increases with temperature.

Figure 11 shows the plot of $\ln \left(\mathrm{j}_{\mathrm{p}}\right) v s .1 / \mathrm{T}$ for the oxidation peak of the adsorbed species. The current densities were higher under illumination than in the dark. The magnitude of the difference, however, decreases when the temperature increases. As the temperature increases the adsorption/desorption is affected by thermal convection of the solution. The good straight lines obtained allow the application of the equation:

$$
\ln \left(\mathrm{j}_{\mathrm{p}}\right)=\text { const }-\mathrm{E}_{\mathrm{a}} * / \mathrm{RT}
$$

where $E_{a} *$ is the apparent activation energy for the process.

The values obtained were $24.9 \mathrm{~kJ} \mathrm{~mol}^{-1}$ and $33.3 \mathrm{~kJ}$ $\mathrm{mol}^{-1}$ for the system under illumination and in the dark, respectively. The incidence of the light on the electrode surface decreases the activation energy for the electrooxi-

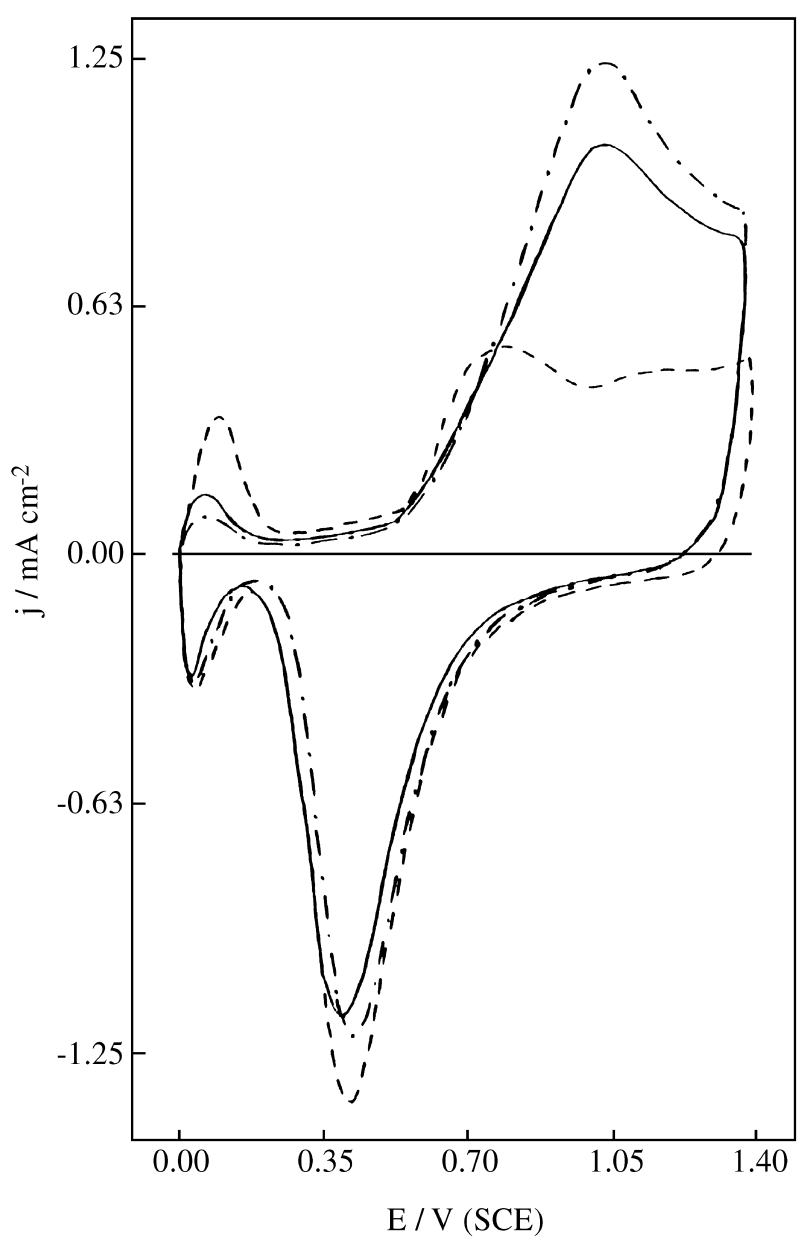

Figure 10. Effect of temperature on the I(E) curves, in the base electrolyte at $25^{\circ} \mathrm{C}$ (---) and, in the presence of allyl alcohol $0.50 \mathrm{mM}, \mathrm{E}_{\text {ads }}=0.0 \mathrm{~V}$ $(\mathrm{SCE}), \mathrm{tads}=180 \mathrm{~s}$, under illumination, $\mathrm{v}=0.80 \mathrm{~V} / \mathrm{s}$, at $25^{\circ} \mathrm{C}(-)$ and $35^{\circ} \mathrm{C}(---)$.

dation of the adsorbed species formed during allyl alcohol adsorption. These data clearly confirm that the incidence of polychromatic light on the electrode surface may affect its interaction with the organic compound. It can be noted that the light could be disperse on the electrode surface as heat. However, this is not the main effect in order to explain the results observed under illumination.

\section{Effect of the potential program}

The voltammograms of $\mathrm{Pt} / \mathrm{Pt}$ in deaerated $1.0 \mathrm{M} \mathrm{HClO}_{4}$ in the absence and presence of the adsorbed species derived from allyl alcohol adsorption are shown in Fig. 12. The potential program is represented in the figure. The effect of the light is also presented.

When the electrode potential is swept into the cathodic potential range as is shown in the potential program, it should be reasonable to assume that a reduction process of the adsorbed species occur. These new species should explain the differences of the voltammogram shapes, by comparing with those observed in Fig. 1. However, the 


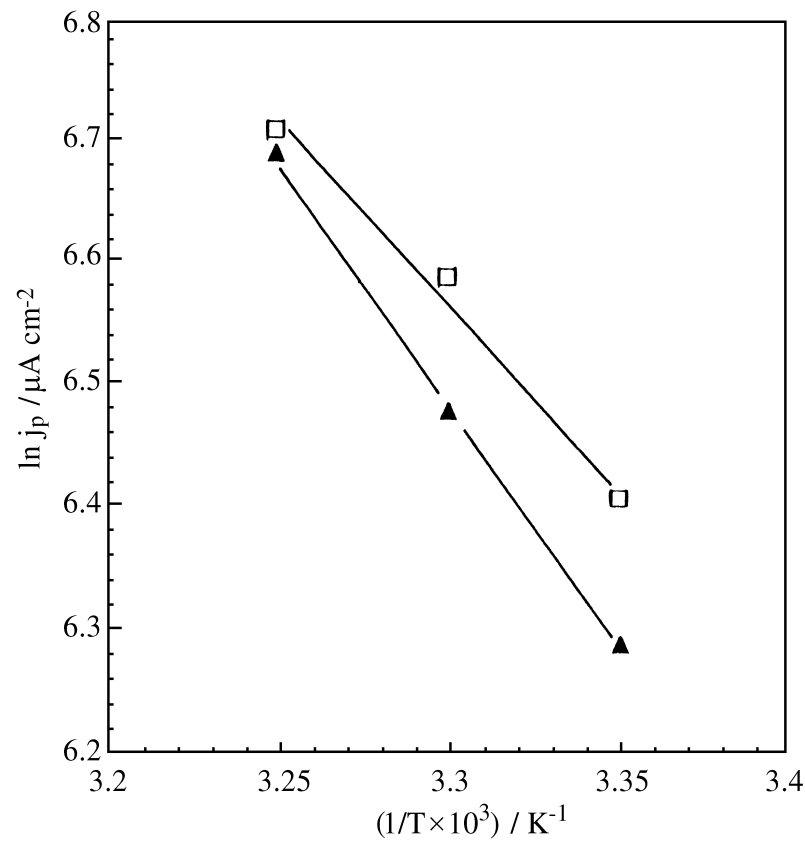

Figure 11. Plot of $\ln \left(\mathrm{j}_{\mathrm{p}}\right) v s .1 / \mathrm{T}$ for the electrooxidation of adsorbed allyl alcohol $0.50 \mathrm{mM}, \mathrm{Eads}=0.0 \mathrm{~V}(\mathrm{SCE}), \mathrm{tads}=180 \mathrm{~s}$, at $\mathrm{v}=0.80 \mathrm{~V} / \mathrm{s}$, in the dark ( $(\mathbf{\Delta})$ and, under illumination $(\square)$.

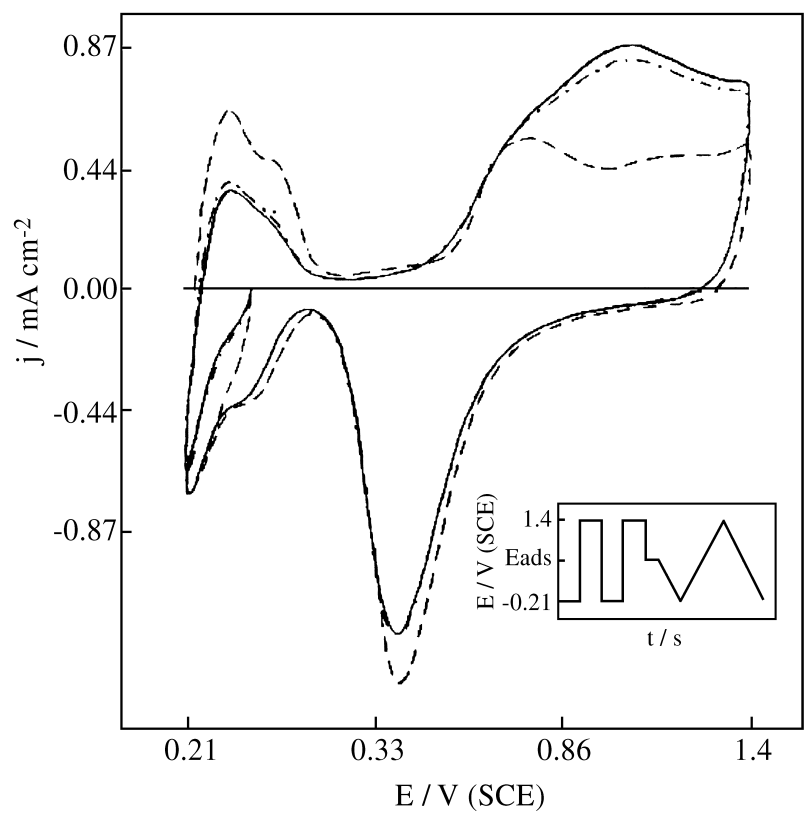

Figure 12. Potentiodynamic I(E) profiles of Pt/Pt electrode in deaerated $\mathrm{HClO}_{4} 1.0 \mathrm{M}$, in the absence (----) and in the presence of allyl alcohol 0.50 $\mathrm{mM}$ at $\mathrm{E}_{\mathrm{ads}}=0.0 \mathrm{~V}(\mathrm{SCE}), \mathrm{t}_{\mathrm{ads}}=180 \mathrm{~s}, \mathrm{v}=0.80 \mathrm{~V} / \mathrm{s}$, in the dark (- - - ) and under illumination (一).

effect of the incidence of light confirms the results observed before.

The number of electrons per sites was calculated by applying the formula:

$$
\mathrm{N}_{\mathrm{eps}}=\mathrm{Q}_{\mathrm{org}} / \mathrm{Q}_{\mathrm{b}}(\mathrm{H})
$$

where $\mathrm{Q}_{\mathrm{b}}(\mathrm{H})$ was related with the quantity of electricity associated with the amount of adsorbed hydrogen blocked by the adsorption of alcohol.

It was found $\mathrm{N}_{\text {eps }}=2.5$ for the system kept in the dark and $\mathrm{N}_{\mathrm{eps}}=2.0$ under illumination. This difference may be an additional confirmation that the incidence of the light on the electrode surface should alter the adsorption mechanism of allyl alcohol. The energy of the light may be absorbed by the adsorbed species. The light energy may increase the oscillation of the adsorbed structure in order to produce new bond conformation on the electrode surface.

\section{Conclusions}

The total electrooxidation process of allyl alcohol on platinized platinum in perchloric acid is represented by the overall reaction:

$$
\mathrm{H}_{2} \mathrm{C}=\mathrm{CHCH}_{2} \mathrm{OH}+5 \mathrm{H}_{2} \mathrm{O} \underset{3 \mathrm{CO}_{2}+16 \mathrm{H}^{+}+16 \mathrm{e}^{-}}{\longrightarrow}
$$

This process occurs, at least partially, through the participation of an adsorbed species on the catalytic surface. The maximum interaction between the adsorbed species and the catalytic surface occurs at around $0.0 \mathrm{~V}$ (SCE) and depends on the adsorption time. The mechanism of the electrooxidation of the adsorbed species formed during allyl alcohol adsorption involves a monoelectronic charge transfer step. In many regards, the data obtained confirm the view that the illumination by polychromatic light on the electrode surface can affect the interaction between platinized platinum and allyl alcohol in deaerated perchloric acid. The quantity of electricity associated with the electrooxidation of the adsorbed species formed during allyl alcohol adsorption is greater under illumination than in the dark. This difference may be either related with a photo-activation of the adsorption reaction that increases the amount of adsorbed species or, with a photo-induced effect on the electrooxidation of the adsorbed species. On the other side, in the hydrogen adsorption/desorption potential range the current densities related with the electrooxidation of adsorbed hydrogen decreases under illumination. This effect could indicate a photo-activation of the adsorption process of the organic compound since more active sites were free regarding to hydrogen adsorption. Another possibility is that new conformations of the adsorbed species are occurring due to the absorption of light.

\section{Acknowledgments}

The authors wish to thank CNPq, CAPES and GTZ/UFSM for the financial support of this work.

\section{References}

1.Lamy, C. Electrochimica Acta 1992, 29, 1581. 
2. Gonçalves, R.S.; Léger, J-M.; Lamy, C. Electrochimica Acta 1988, 33, 1581.

3. Pastor, E.; Schmidt, V.M.; Iwasita, T.; Arévalo, M.C.; González, S.; Arvia, A.J. Electrochimica Acta 1993, 38, 1337.

4.Pastor, E.; Wasmus; S.; Iwasita, T.; Arévalo, M.C.; González, S.; Arvia, A.J. J. Electroanal. Chem. 1993, $353,81$.

5. Gonçalves, R.S.; Mallmann, J.A.; Grabner, E.W. Electrochimica Acta 1995, 40, 1165.
6. Iwasita, T.; Pastor, E. Electrochimica Acta 1994, 39, 531.

7.Hitmi, H.; Belgsir, E.M.; Léger, J.-M.; Lamy, C.; Lezna, R.O. Electrochimica Acta 1994, 39, 407.

8. Nart, F.C.; Iwasita, T. J. Electroanal. Chem. 1991, 308, 277.

9. Wieckowski, A.; Zelenay, P.; Varga, K. J. Chim. 1991, 88, 1247.

10. Trasatti, S. Electrochimica Acta 1992, 37, 2137. 